\title{
Teologia de J. Ratzinger / Magistério de Bento XVI
}

Orientador: Prof. Antonio Luiz Catelan Ferreira

Pesquisador: Jodeilson Gualberto de Oliveira

Fonte: Voluntário

\section{Introdução}

O presente trabalho foi desenvolvido por meio de pesquisa sobre a Teologia de J. Ratzinger / Magistério de Bento XVI realizado conjuntamente com a Sociedade Ratzinger Brasil, a Fondazione Vaticana Joseph Ratzinger (Itália) e o Institut Papst Benedikt XVI (Regensburg). Um tema recorrente, e que caracteriza sua inteira produção, é o da relação entre fé e política. Neste âmbito, esta referida pesquisa foi elaborada pela análise dos discursos que envolvem a temática da fé e sua relação com a política durante o pontificado de Bento XVI. O contraponto entre os dois temas (um ad intra e outro ad extra) tem por finalidade manter unidos dois aspectos da teologia de J. Ratzinger e do Magistério de Bento XVI e compreender sua peculiaridade.

\section{Objetivos}

Objetivo Geral: Preparar uma publicação de textos seletos de Bento XVI sobre o tema "Fé e política", com introdução e notas.

Objetivos Específicos: I) Iniciar os estudos na metodologia do estudo crítico de temas teológicos, especificamente da teologia de J. Ratzinger e no Magistério de Bento XVI; II) Selecionar textos do Magistério de Bento XVI que sejam pertinentes à questão da relação entre fé e política e especificamente significativos para sua compreensão; III) Analisar os textos, levando em conta os estudos (teses, livros, capítulos de livros e artigos) que visam sobre a mesma questão; IV) Participar da discussão da proposta da introdução e de notas necessárias para contextualizá-los na história da questão e no conjunto do Magistério de Bento XVI. 